\title{
EDITORIAL - EDIÇÃO ESPECIAL
}

\section{LEITURA, ARTE E PANDEMIA}

Rosana Baptistella
Marcus Novaes

Bem vindos à Edição Especial da Revista Linha Mestra, pensada, elaborada e produzida durante a pandemia.

Em reunião da diretoria da ALB em abril do presente ano, quando ainda estávamos no início do isolamento social, decidimos que a Linha Mestra teria uma edição dedicada a reflexões acerca deste momento. Uma necessidade com a qual nos deparamos, por estarmos imersos em um período como nunca tínhamos vivido, afetando a todos profundamente, nos diversos campos da vida.

Após um debate com este tema, num encontro virtual promovido pela Associação de Docentes da Unicamp (ADunicamp) no mês de maio, convidamos os debatedores Alexandro Paixão e Ana Archangelo, professores da Faculdade de Educação da Unicamp para a organização do dossiê que aqui se apresenta. Pandemia \& Sobrevivência - Leituras para tempos difíceis é composto por sete artigos escritos por autores que atuam em campos diversos: filosofia, sociologia, pedagogia, psicanálise, medicina, entre outros, propondo reflexões profundas, sensíveis e necessárias.

Neste mesmo período, uma convocatória artística era organizada por grupos de pesquisa da Universidade Federal do Tocantins, com o intuito de selecionar produções visuais, cênicas, midiáticas, textuais, entre outras, enviadas por artistas de diversos países, imersos no processo pandêmico. Amanda Leite, uma das organizadoras, contatou-nos para convidar a ALB a ser parceira esta empreitada. O resultado, uma bonita e potente Revista de Artista intitulada Pausa na Rede - expressões artísticas em tempos de pandemia, vem como suplemento desta edição especial da Linha Mestra.

Esta confluência de desejos e iniciativas coletivas é publicada agora, após atravessarmos o outono, o inverno e chegarmos ao mês em que terá início a primavera.

Esperamos - esperançando -, que esta edição, realmente especial para nós, chegue a você, leitor, como um espaço para estarmos juntos. Que seja um respiro, quiçá um alívio, em tempos tão brutos e, por isso mesmo, tão necessitados de delicadezas. 